\title{
Calcareous algae from the Ordovician succession (Thango Formation) of the Spiti Basin, Tethys Himalaya, India
}

\author{
SHIVANI PANDEY* and SURAJ K. PARCHA \\ Wadia Institute of Himalayan Geology, 33 GMS Road, Dehradun - 248001, India; \\ e-mail: pandeshivani@gmail.com, parchask@wihg.res.in,parchask@gmail.com \\ Received 27 December 2017; accepted for publication 11 June 2018
}

\begin{abstract}
The calcareous algae Dasyporella silurica, Moniliporella multipora and Vermiporella fragilis are reported for the first time from the Middle Ordovician (Dapingian to Darriwilian) Thango Formation of the Spiti Basin of northern India (Pin Valley, Tethys Himalaya). Moniliporella multipora is reported for the first time from the entire Spiti Basin. This algal assemblage is broadly comparable to that of the directly overlying Takche (=Pin) Formation in the Spiti Basin, as well as that reported from the Ordovician succession of the Tarim Basin and from Kazakhstan. The presence of these calcareous algae is of biogeographical and biostratigraphical significance as it indicates a shallow marine depositional environment for the Thango Formation of the Spiti Basin.
\end{abstract}

KEYWORDS: Algae, depositional environment, biogeography, Middle Ordovician

\section{INTRODUCTION}

We report calcareous green algae from the Ordovician succession of Sanugba Group exposed in the Pin Valley (Figs 1, 2). The present work is focused on the Thango Formation (Dapingian to Darriwilian stages of Ordovician), which lies above the Kunzum La Formation in the Pin Valley, Spiti Basin. Calcareous algae are used to reconstruct the ancient sedimentary environment, as they are widespread in various facies of Ordovician carbonate complexes. Calcareous algal remains provide useful information about the palaeoenvironment and were most intense in reef and related shallow-water facies (Riding \& Fan 2001). The fossil record of these calcified algae extends back from the Precambrian (600 million years ago).

In the Tethys Himalaya, Reed (1912) reported calcareous algae from the Ordovician succession of the Spiti Basin. He mentioned them as "incertae sedis" and compared them with

\footnotetext{
Corresponding author
}

Pasceolus and Apidium. Pia (1927) interpreted Reed's Apidium as calcareous algae, and Pasceolus? shianensis as dasyclad Coelosphaeridium. Bhargava and Bassi (1986) reported calcareous algae from the Ordovician succession of the Kinnaur region (Himachal Himalaya), and Kato et al. (1987) reported them from the Spiti Basin. Hubmann and Suttner (2007) described calcareous algae from the Upper OrdovicianLower Silurian succession (Takche=Pin Formation) of the Pin section. Recently, Sinha and Trampisch (2013) reported calcareous algae from the Lower Palaeozoic of the Shiala Formation (Uttarakhand Garhwal region).

The present study deals with the carbonate beds of the Middle Ordovician succession (Thango Formation) of the Pin Valley in the Spiti Basin, which contains a wide variety of marine calcareous algae along with other microfossil assemblages. Three calcareous algal taxa were identified from the studied section: Dasyporella, Vermiporella and Moniliporella. The Upper Ordovician age of the lower 


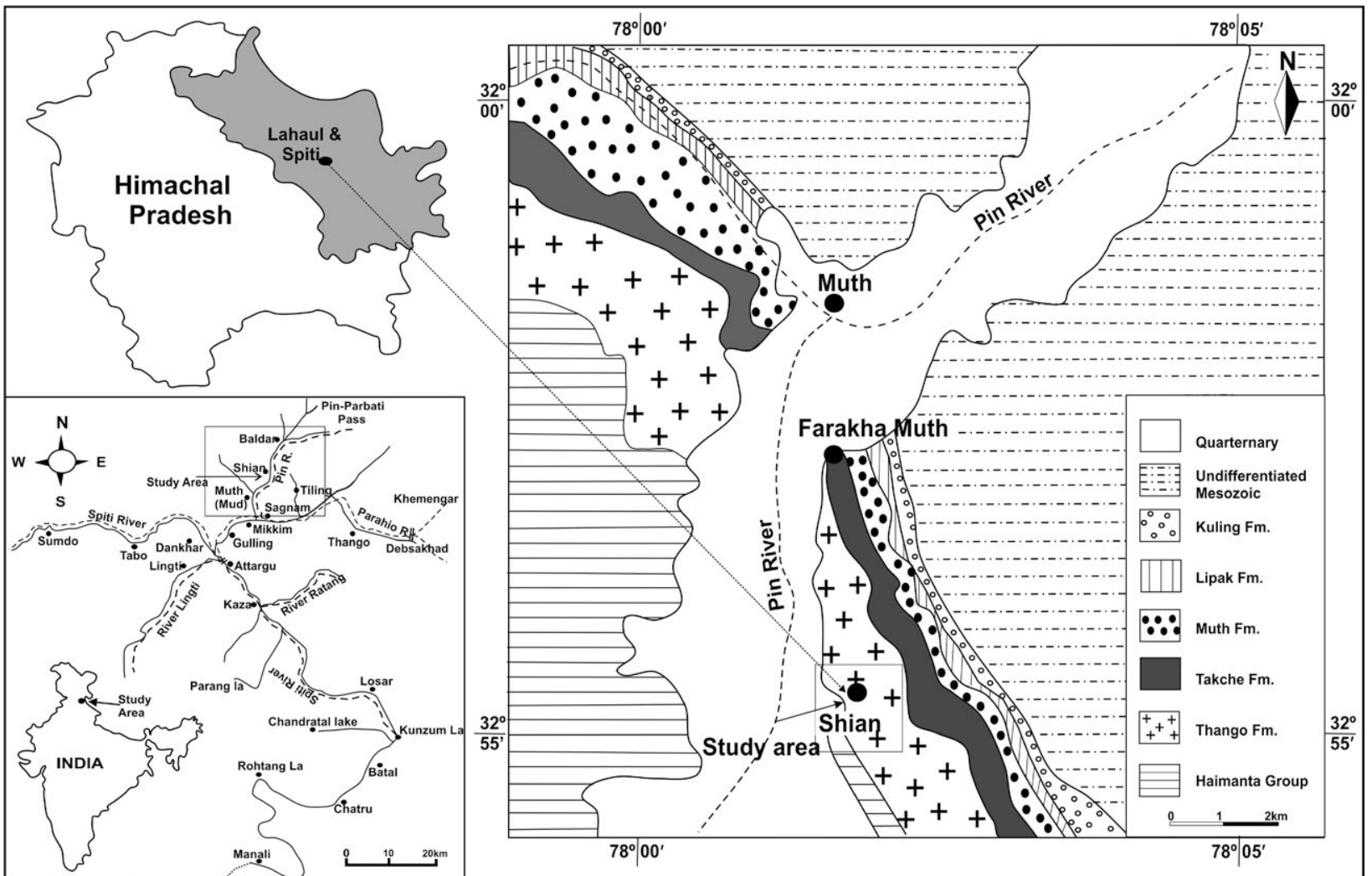

Fig. 1. Geological map, with route map of the Pin Valley area of the Spiti Basin, showing the Paleozoic successions and study area (modified after Parcha \& Pandey 2011b)

part of the Pin Valley has been conodont-dated (Amorphognathus ordovicicus Zone) and verified by both megafauna and coeval conodonts (Suttner \& Ernst 2007). The present reported algal forms indicate Middle Ordovician age, as these algae were reported $72 \mathrm{~m}$ below the level where Hubmann \& Suttner (2007) reported algae. Here we attempt to interpret the palaeoenvironment distribution of the calcareous algae during the Ordovician, and discuss the taxonomic classification of the reported algae.

\section{GEOLOGICAL SETTING}

Stoliczkai (1865), Greishbach (1891), Srikantia (1981) and Bhargava et al. (1991) gave detailed geological overviews of the Spiti Basin. Greishbach (1891) and Bhargava \& Bassi (1998) recognized the unconformity between the Cambrian and overlying Ordovician rock. Later, Sriknatia and Bhargava (1998) grouped the rocks ranging in age from the Neoproterozoic to Cambrian in the Haimanta Group and overlying succession above the unconformity (Ordovician to Silurian) in the Sanugba Group. The present work is focused on the Thango Formation, which lies above the unconformity in the Pin Valley of the Spiti Basin (Fig. 2). Goel and Nair (1977) used the term "Shian Formation" for the Ordovician rocks and "Pin Formation" for the Silurian rocks exposed in the Pin Valley. Srikantia (1981) used the terms "Thango" and "Takche" for the successions ranging from the Ordovician to Silurian. Bhargava and Bassi $(1986,1998)$ and Parcha and Pandey (2011a, b) adopted the terminology given by Srikantia (1981), while Ranga Rao et al. (1982), Garzanti et al. (1986), Talent et al. (1988), Bagati (1990) Bagati et al. (1991), Dragnites (2000), Hubmann and Suttner (2007) and Suttner and Ernst (2007) used the terms "Shian" and "Pin" instead of "Thango" and "Takche". Recently, Bhargava (2008) considered "Thango" and "Takche" to be more suitable, as these formations are best exposed in their type sections. In the present paper we adopt the classification given by Bhargava (2008) (Tab. 1).

The study focuses on the Thango Formation of the Pin Valley, exposed on the left bank of the Pin River facing Babha Joth (Fig. 2). The succession consists mainly of buff-coloured sandstone, shale, siltstone and dolomites with minor grits and occasional intraformational conglomerates. The Thango Formation in the 
Table 1. Classification of Lower Palaeozoic rocks of the Spiti Basin given by various workers

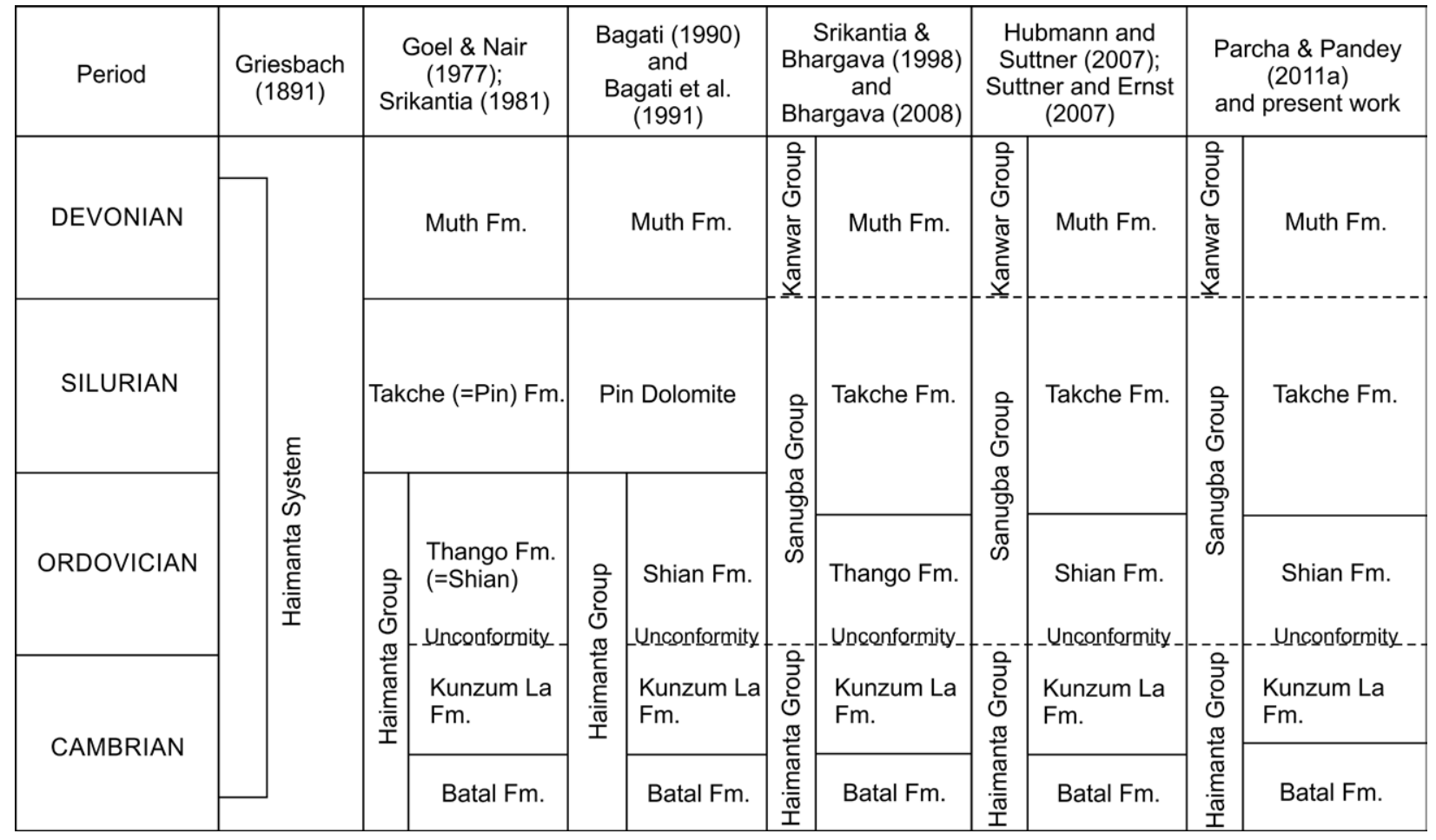
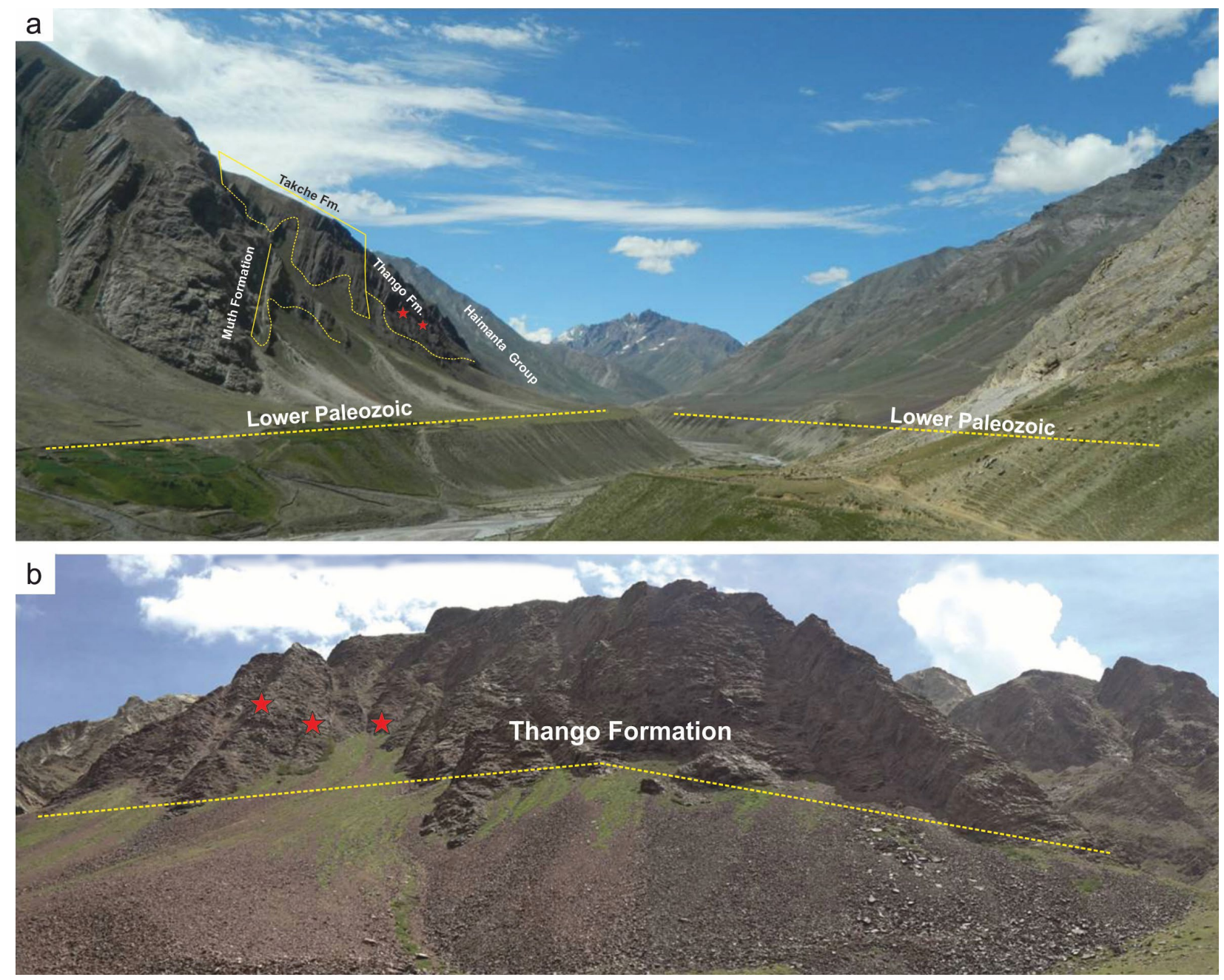

Fig. 2. Panoramic view of the Pin Valley, Spiti Basin. (a) Lower Palaeozoic succession exposed in the Pin Valley (b) Close view of the studied Thango Formation in the Pin Valley 
Spiti Basin appears to range from Early Ordovician to early Late Ordovician, as indicated by Phycodes circinatum and algae Prismocorollina sp. associated with corals, bryozoans and invertebrates, whereas assignments based on coral, conodonts and algal remains place the age of the Takche Formation in the range from Late Ordovician to Middle/early Late Silurian (Bhargava \& Bassi 1998, Srikantia \& Bhargava 1998, Bhargava 2008). The Thango Formation ranges in age from Lower Ordovician to Middle Ordovician (Floian to Darriwilian), as the basal part of the formation is covered by conglomerates representing an angular unconformity in the entire Spiti Basin. The overlying Takche (= Pin) Formation has gradational to intercalated contact with the Thango Formation.

\section{MATERIAL AND METHODS}

Fourteen thin sections of carbonate rocks were prepared from samples collected from the Ordovician section of the Thango Formation, which lies in Shian Kogma village opposite Mud village (type locality of Muth Formation) in the Pin Valley. The thin sections, bearing algae and other microfossils, were prepared and examined with a Nikon Eclipse E600Pol microscope. The reported material is housed in the Repository of the Wadia Institute of the Himalayan Geology Museum, Dehradun, India (Repository numbers WIMF/A/4668 to WIMF/A/4680).

\section{SYSTEMATIC PALAEONTOLOGY}

Order: DASYCLADALES Pascher 1931

Family: SELETONELLACEAE (Korde 1950) Bassoullet et al. 1975

Tribe: DASYPORELLEAE (Pia 1920) Bassoullet et al. 1979

Genus: Dasyporella Stolley 1893

Dasyporella silurica Stolley 1893

Plate 1, figs 2-4; Plate 2, fig. 3; Plate 3, figs 1-3

Type species: Dasyporella silurica Stolley 1893

Description. Well-preserved thallus with broad central cavity. Cylindrical to sub-cylin- drical calcified tube, moderately thick wall pierced at right angles by narrow, closely spaced tubular pores, slightly enlarged at distal end. Overall external thallus size 1000$5500 \mu \mathrm{m}$. Internal diameter (d) $800-2700 \mu \mathrm{m}$, external diameter (D) 1000-3200 $\mu \mathrm{m}$. Pore diameter 50-70 $\mu \mathrm{m}$, pore length $60-85 \mu \mathrm{m}$, pore interspace $30-45 \mu \mathrm{m}$.

Remarks. The classification of the Dasyporelleae was reviewed by Berger and Kaever (1992). The basic character of Dasyporella is its simple form, broad central cavity, unbranched thallus and comparatively thick wall (Stolley 1893). The presently described specimen shows resemblance to the genus Dasyporella (Pia 1920) in the nature of the thick wall and broad central cavity. The described genus shows morphological dimensions mostly similar to the form defined by Riding and Fan (2001) and Sinha and Trampisch (2013). The specimen resembles Dasyporella silurica described by Riding and Fan (2001) from the Ordovician of the Tarim Basin and by Sinha and Trampisch (2013) from the Ordovician succession of the Shiala Formation in the Garhwal region due to its broad central cavity, thick wall and closely spaced pores. Bharagava and Bassi (1986) described Dasyporella from the Kinnaur Basin but did not give a morphological description; Hubmann and Suttner (2007) gave external thallus size and wall thickness. The reported form differs from Dasyporella sp. described by Hubmann and Suttner (2007) from the Ordovician of Spiti and by Bhargava and Bassi (1986) from the Silurian of the Kinnaur Basin in its sub-cylindrical thallus and in the nature of the central cavity.

\section{Family: Moniliporellaceae \\ Gnilovskaya 1972}

Genus: Moniliporella Gnilovskaya 1972

Moniliporella multipora Riding \& Fan 2001

Plate 1, fig. 1; Plate 3, fig. 4

\section{Type species: Moniliporella multipora (Stolley) Riding \& Fan 2001}

Description. Sub-cylindrical tube-like structure with broad central cavity with filled pores. Longitudinal section shows constriction, with regular arrangement of branches around 

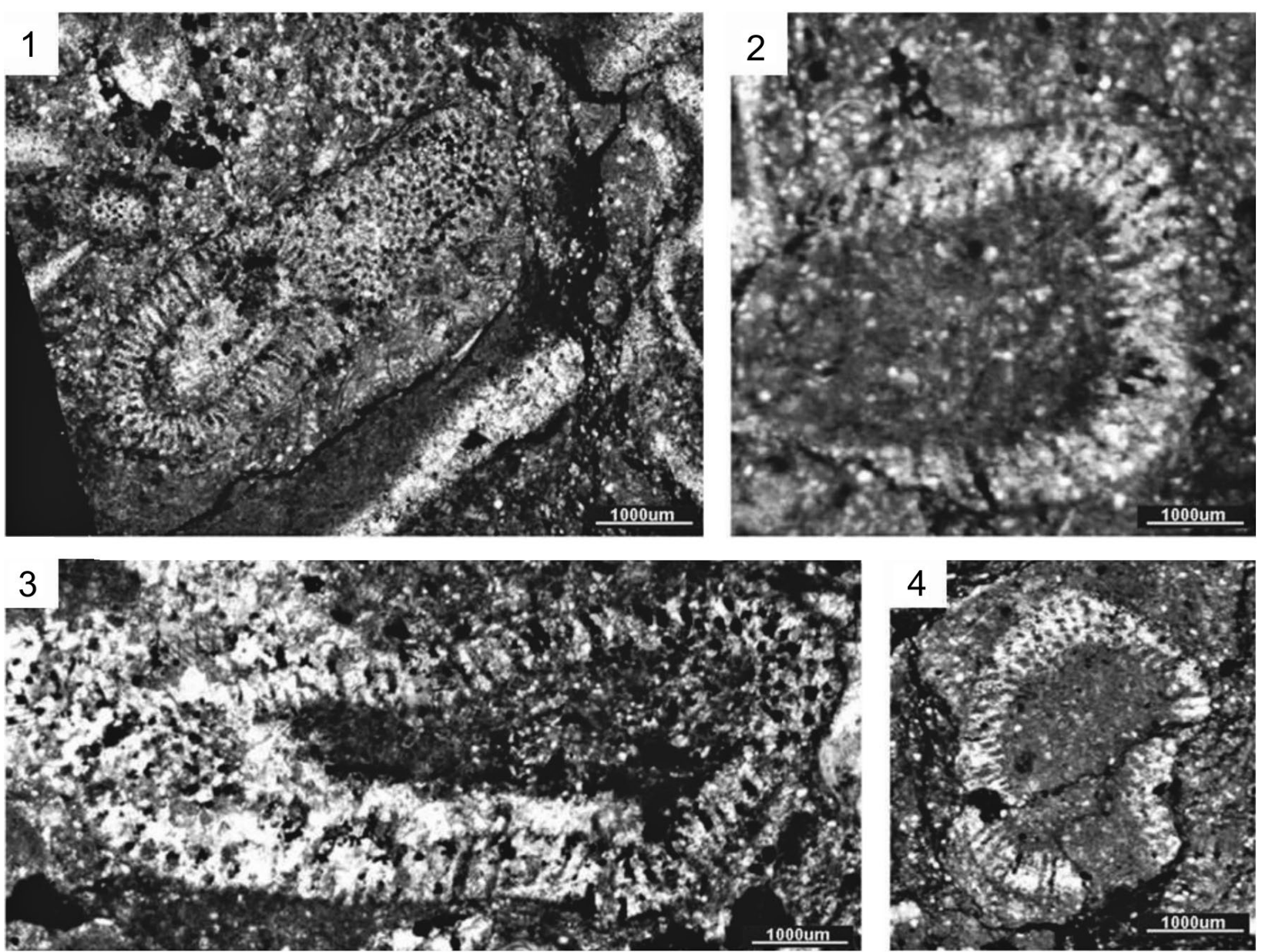

Plate 1. Fig. 1. Moniliporella multipora Gnilovskaya, calcareous alga from the Ordovician succession of the Thango Formation in the Pin valley, Spiti Basin. 1, WIMF/A/4673; Figs 2-4. Dasyporella silurica Stolley. 2 - WIMF/A/4670; 3 - WIMF/A/4676; 4 - WIMF/A/4672

central cavity and pores between branches. Surface mostly covered with densely distributed, rounded pores at right angles to central cavity, tube-like thick wall with closely spaced pores. Total length of thallus $3200-4800 \mu \mathrm{m}$, internal diameter (d) 400-600 $\mu \mathrm{m}$, external diameter (D) 1600-2000 $\mu \mathrm{m}$. Pore interspace 50-63 $\mu \mathrm{m}$, pore diameter $32-48 \mu \mathrm{m}$.

Re m a rks. The specimens resemble the genus Moniliporella in its sub-cylindrical thallus and also its tube-like structure with a broad central cavity with filled pores. Based on its irregular form and comparatively thinner wall, Stolley (1893) differentiated Dasyporella multipora (Moniliporella multipora) from Dasyporella silurica and other species of Dasyporella. The more complex thallus shape of Dasyporella multipora, with well-defined constrictions, appears to be identical to Moniliporella camer$a t a$. The described specimens differ from Dasyporella silurica and other forms of Dasyporella in having a sub-cylindrical thallus with a long calcified tube, which is the most significant feature of Moniliporella. The present specimens show similarity in the nature of the subcylindrical thallus, calcified tube, thick wall and broad central cavity with Moniliporella multipora described by Riding and Fan (2001) from the Ordovician of the Tarim Basin and by Sinha and Trampisch (2013) from the Ordovician of the Shiala Formation of the Garhwal region, India.

Class ULVOPHYCEAE

Mattox and Stewart 1984

Genus: Vermiporella Stolley 1893

Vermiporella fragilis Stolley 1893

Plate 2, figs. 1, 2, 4, 5, 6

Type species: Vermiporella fragilis Stolley 1893

Description. Cylindrical thallus, irregularly ramified with numerous straight cylindrical branches. Surface of tubes covered with 

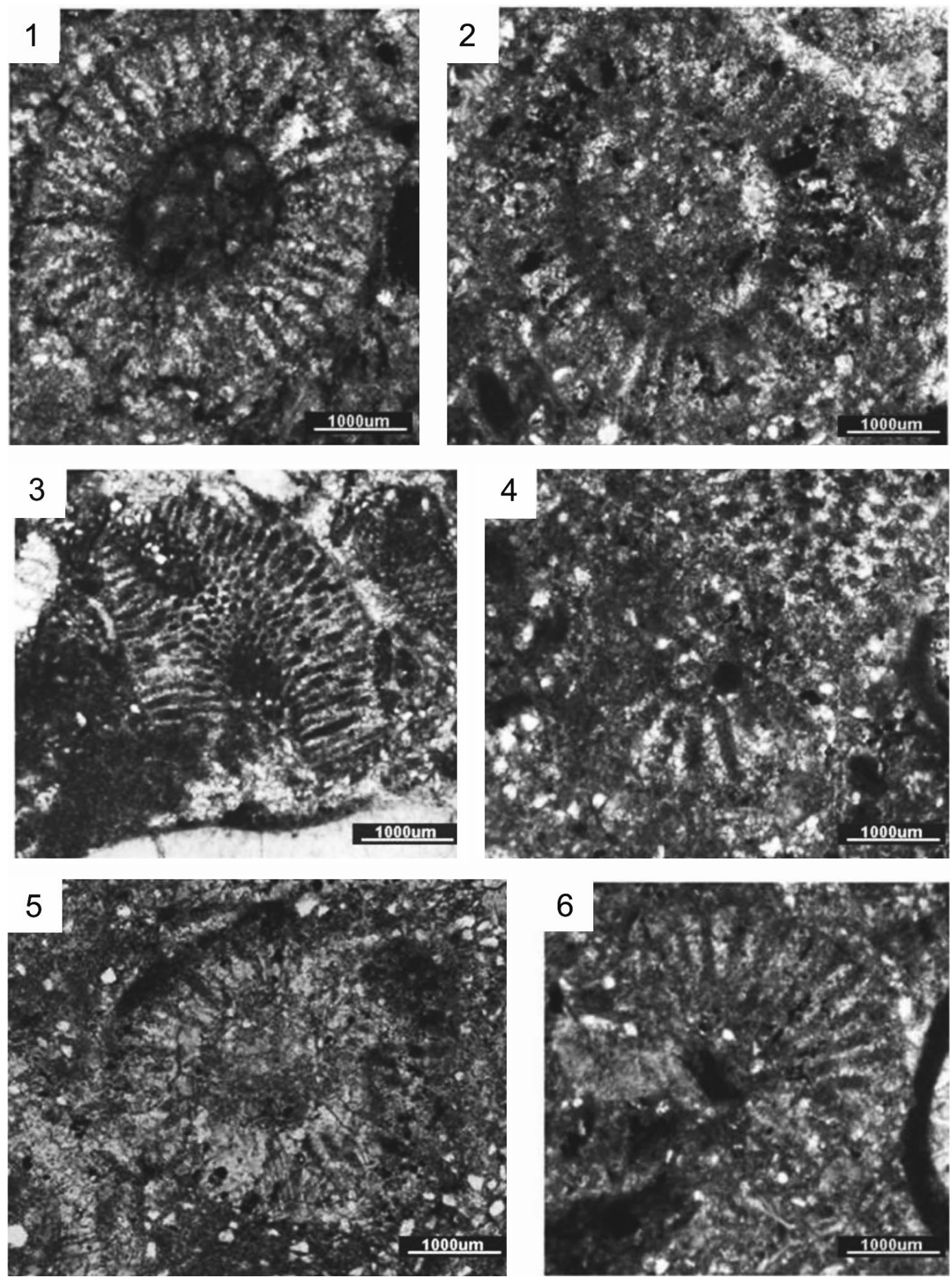

Plate 2. Figs 1, 2, 4, 5, 6. Vermiporella fragilis Stolley, calcareous algae from the Ordovician succession of the Thango Formation in the Pin valley, Spiti Basin. 1 - WIMF/A/4674; 2 - WIMF/A/4675; 4 - WIMF/A/4670; 5 - WIMF/A/4668; 6 -WIMF/A/4669; Fig. 3. Dasyporella silurica Stolley, WIMF/A/4679

densely distributed rounded pores. Overall external thallus length $900-3100 \mu \mathrm{m}$. Internal diameter (d) 140-300 $\mu \mathrm{m}$, external diameter (D) 240-460 $\mu \mathrm{m}$, wall thickness 55-65 $\mu \mathrm{m}$, pore diameter $30-45 \mu \mathrm{m}$.

Remarks. The genus Vermiporella shows some similarity to the genus Dasycladus and so is regarded as dasycladalean (Tappan
1980, Berger \& Kaever 1992). Kozlowski and Kazmierczak (1968) described internal microscopic details of Vermiporella fragilis that suggest a comparison with ulotichalean green algae. Riding and Fan (2001), Lewis and McCourt (2004) and Feng et al. (2010) placed Vermiporella in the Ulyophyceae, which includes Dasycladales and Ulotrichales. Vermiporella is a widely reported genus, characterized by 

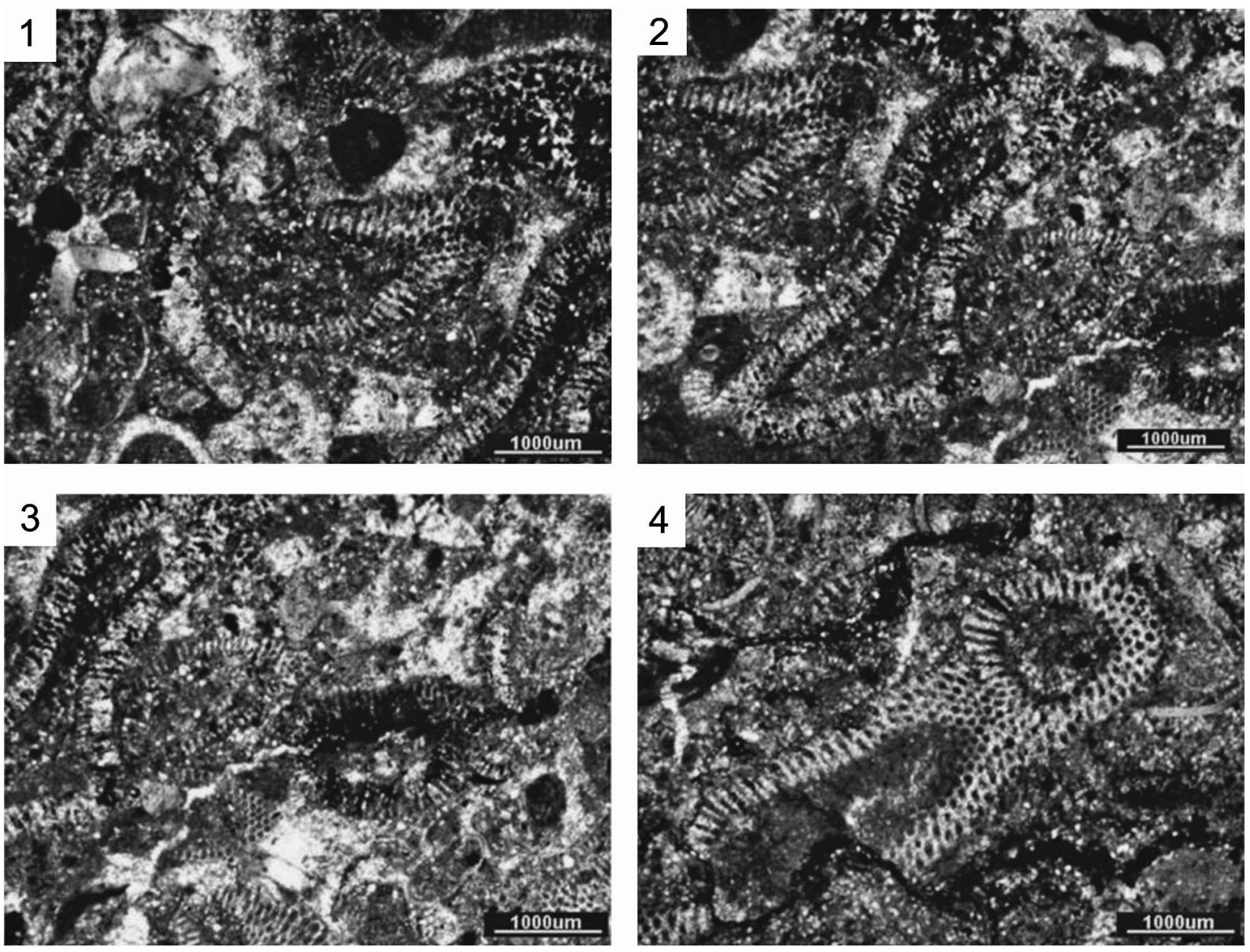

Plate 3. Figs 1-3. Daysporella silurica Stolley, calcareous algae from the Ordovician succession of the Thango Formation in the Pin valley, Spiti Basin. 1 - WIMF/A/4679; 2 - WIMF/A/4680; 3 - WIMF/A/4678; Fig. 4. Moniliporella multipora Gnilovskaya, WIMF/A/4677

its external lobed form and thin wall which distinguish it from Dasyporella. The presently described specimens are grouped under Vermiporella fragilis due to their cylindrical thallus, irregular ramified thallus and numerous straight branches, described by Riding and Fan (2001) and Feng et al. (2010).

\section{STRATIGRAPHIC AND PALAEOENVIRONMENTAL SIGNIFICANCE}

The presence of calcareous algae in the Ordovician succession reveals that these successions developed within a shallow sea. Extensive deposition of carbonates and other environmental conditions fostered the development of algae (Maithy et al. 1999). These calcareous algae are major sources of primary production during their life and contribute to the buildup of carbonate sediments in marine environments after their decay (Hillis-Collinvaux 1980, Drew 1983,
Multer 1988, Payri 1988). The described calcareous algae provide useful information about the palaeoenvironmental setting and also complement interpretations based on other biota and on the depositional features observed during studies of the region. The presence of calcified green algae in the studied section indicates shallow marine to near-shore environmental conditions followed by different stages of regression and transgression.

Vermiporella has been considered an important genus as it is the major contributor to the backreef (Opalinski \& Harland 1981, Webby 2002) and is among the oldest calcified fossils, which appears in the Middle Cambrian and became extinct in the Permian (Herak et al. 1977, Riding \& Fan 2001). Gnilovskaya (1965) reported $V$. fragilis, $V$. wesenbergensis, $V$. acerosa and $V$. diffluens from the Ordovician of the Tarbagatay Range (Kazakhstan). Stolley (1893) described $V$. fragilis from the Upper Ordovician of northern Germany. The genus is also reported from the Upper Ordovician of Poland 
(Kozlowski \& Kazmierczak 1968), Upper Ordovician of Scotland (Elliott 1972) Lower Ordovician of eastern North America (Roux 1991) and Upper Ordovician of the Lianglitage Formation in the Tarim Basin (Liu et al. 2012).

The genus Dasyporella ranges in age from Middle Ordovician to Permian. Apart from the Spiti Basin, the genus is reported from Middle to Upper Ordovician successions of the Tarim Basin in China, eastern Kazakhstan, Utah and Nevada in the USA, and Norway, and from Silurian successions of northern California. Here we report Moniliporella for the first time from the Middle Ordovician succession of the Pin Valley in the Spiti Basin. The occurrence of Moniliporella in the Pin Valley of India as well as from the Tarim Basin and Kazakhstan suggests a regional link between these three regions.

The distribution of these algae in the Ordovician, particularly in India, the Tarim Basin, Kazakhstan, Baltica and North America indicates that all these areas were on the $0-30^{\circ}$ latitudinal belt during the Ordovician, reflecting continental reconstruction. It has also been observed that the latitudinal positions of India and the Tarim Basin were adjacent to each other, possibly due to plate reconstruction during Ordovician-Silurian times (Smith 2001, Sinha \& Trampisch 2013). The floristic similarities between these widely separated regions indicates that these algal structures developed through the Ordovician and further to the end of the Permian, and were cosmopolitan. In the light of these studies, we are presently attempting to determine the palaeoenvironmental conditions of these calcareous algae and to correlate them at genus level with comparable successions of Kazakhstan, the Tarim Basin and Kinnaur Basin.

\section{CONCLUSION}

The Ordovician succession of the Pin Valley of Spiti Basin is composed of mixed carbonate and siliciclastic sedimentary rocks. The described calcareous algae from this section have a relatively wide stratigraphic distribution during the Ordovician and thus are not of biostratigraphic relevance, but can be used as indicators, particularly for identifying shallow marine, warm, well-oxygenated and relatively high-energy environments. The presence of calcified green algae in the carbonate beds of the
Ordovician succession indicates shallow marine to near-shore environmental conditions followed by different stages of regression and transgression. The distribution of calcareous algae in the Tarim Basin, Kazakhstan, Baltica, North America, Scotland and India indicates that all these areas were along the $0-30^{\circ}$ latitudinal belt during the Ordovician period. It further suggests a regional link between India, the Tarim Basin and Kazakhstan. The floristic similarities between widely separated areas suggests these calcareous algae to be cosmopolitan.

\section{ACKNOWLEDGEMENTS}

We are grateful to Dr. Meera Tewari (Director, Wadia Institute of Himalayan Geology, Dehradun) for providing facilities and for permission to publish this work. This work was carried out under Project SR/FTP/ ES-111/20014 funded by the SERB (Science and Engineering Research Board) under the Department of Science and Technology, Government of India. We thank to the reviewers for their supportive suggestions and comments which helped to improve the final manuscript.

\section{REFERENCES}

BAGATI T.N. 1990. Lithostratigraphy and facies variation in the Spiti Basin (Tethys), Himachal Pradesh, India. J. Himalayan Geol., 1(1): 35-47.

BAGATI T.N., KUMAR R. \& GHOSH S.K. 1991. Regressive-transgressive sedimentation in the Ordovician sequence of the Spiti (Tethyan) Basin, Himachal Pradesh, India. Sediment. Geol., 73: 171-184.

BASSOULLET J.P., BERNIER P., DELOFFRE R., GENOT P., JAFFREZO M., POIGNANT A.F. \& SEGONZAC G. 1975. Réflexions surla systématique des Dasycladales fossiles. Etude critique de la terminologie et importance relative des critéres de classification. Geobios, 8: 259-290.

BASSOULLET J.P., BERNIER P., DELOFFRE R., GENOT P., JAFFREZO M., POIGNANT A.F. \& SEGONZAC G. 1979. Classification criteria of fossil Dasycladales: 154-166. In: Flugel E. (ed.) Fossil Algae, Berlin-Heidelberg-New York: Springer.

BERGER S. \& KAEVER M.J. 1992. Dasycladales. An illustrated monograph of a fascinating algal order. Georg Thieme Verlag, Stuttgart, 247 pp.

BHARGAVA O.N. 2008. An update of introduction to the Spiti Geology. J. Palaeontol. Soc. India, 53(2): 113-128.

BHARGAVA O.N. \& BASSI U.K. 1986. Silurian reefal buildups, Spiti-Kinnaur, Himachal Himalaya, India. Facies, 15: 35-52.

BHARGAVA O.N. \& BASSI U.K. 1998. Geology of Spiti-Kinnaur, Himachal Himalaya. Memoirs of Geological Survey of India, 124: 210. 
BHARGAVA O.N, SRIVASTAVA R.N. \& GADHOKE S.K. 1991. Proterozoic-Palaeozoic Spiti Sedimentary Basin: 236-260. In: Tandon S.K. et al. (eds) Sedimentary Basins of India: Tectonic context. Gyanodaya Prakashan, Nainital.

DRAGNITS E. 2000. The Muth Formation in the Pin Valley (Spiti, N-India): Depositional Environment and Ichnofauna of a Lower Devonian Barrier Island System. Ph.D. thesis, University of Vienna.

DREW E.A. 1983. Halimeda biomass growth rate and sediment generation on reefs in the Central Great Barrier Reef Province. Coral Reefs, 2: 101-110.

EISENACK A. 1936. Die Form des Thallus der Siphonee Vermiporella. Ztschr. Geschiebef. Flachlandsgeol., 12(4): 184-186.

ELLIOTT G.F. 1972. Lower Palaeozoic Green Algae from Southern Scotland, and their Evolutionary Significance. Bull. Brit. Mus. Nat. Hist., Geol. 22(2): 355-376.

FENG Q., GONG Y.M \& RIDING R. 2010. Mid-late Devonian calcified marine algae and cyanobacteria, South China. J. Paleontol., 84(4): 569-587.

GARZANTI E., CASNEDI R. \& JADOUL F. 1986. Sedimentary evidence of a Cambro-Ordovician orogenic event in the Northwestern Himalaya. Sedimentary Geology, 48: 237-265.

GNILOVSKAYA M.V. 1965. Ordovician algae of the genus Vermiporella from Tarbagatay Range. J. Int. Geol. Rev., 7(12): 2105-2114.

GNILOVSKAYA M.V. 1972. Izvestkovye vodorosli srednego i pozdnego ordovika Vostochnogo Kazakhstan. USSR Academy of Sciences, Institute of Precambrian Geology and Geochronology, Nauka, Leningrad, $196 \mathrm{p}$.

GOEL R.K. \& NAIR N.G.K. 1977. The Spiti OrdovicianSilurian succession. J. Geol. Soc. India, 18(1): 47-48.

GRIESBACH C.L. 1891. Geology of the Central Himalayas. Memoir Geol. Surv. India, 23: 1-232.

HERAK M., KOCHANSKY-DEVIDE V. \& GUSIC I. 1977. The Development of the Dasyclad Algae through the Ages. In: E. Flügel (ed.), Fossil Algae, Springer Verlag Berlin-Heidelberg.

HILLS-COLINVAUX L. 1980. Ecology and taxonomy of Halimeds: Primaary producer of coral reefs: 1-327. In: Blaxter J.H.S., Russel F.S., Young M. (eds) Advance in marine biology, 17, Academic Press, New York.

HUBMANN B. \& SUTTNER T. 2007. Calcimicrobes and calcareous algae of the Pin Formation (NW Himalayas, India): a contribution to the 'Ordovician Flora'. Acta Palaeontol. Sin. (Special issue), 46 (Suppl.): 188-193, Beijing.

KATO M., GOEL R.K. \& SRIVASTAVA S.S. 1987. Ordovician algae from, Spiti, India. Journal of the Facuulty of Sciences, Hokkaido University, Series I, 22(2): 313-323.

KORDE K.B. 1950. Ostatki vodorosley iz kembriya Kazakhstana. Doklady Akademii Nauk SSSR, 73(4): 809-812.
KOZLOWSKI R. \& KAZMIERCZAK J. 1968. On two Ordovician calcareous algae. Acta Palaeontol. Pol., 13: 325-346.

LEWIS L.A. \& MCCOURT R.M. 2004. Green algae and the origin of land plants. Am. J. Bot., 91: 1535-1556.

LIU L., YANG H.-J. \& WU Y.S. 2012. Calcareous algae from the Upper Ordovician Lianglitage Formation in the Tarim Basin, Xinjiang, China. Acta Micropalaeontol. Sin., 29(1): 18-38.

MAITHY P.K., GHOSH A.K. \& KUMAR G. 1999. First report of Dasycladacean Alga-Cyclocrinites from the Ordovician of Takche Formation, Spiti, India. J. Geol. Soc. India, 54: 379-385.

MATTOX K.R. \& STEWART K.D. 1984. Classification of the green algae: a concept based on comparative cytology: 29-72. In: Irvine D.E.G. \& John D.M. (eds). The systematics of green algae. Academic Press, London.

MULTER H.G. 1988. Growth rate, ultrastructure and sediment contribution of Halimeda incrassata and Halimeda monile, Nonsuch and Falmouth Bays, Antiqua, W.I.: Coral Reefs, 6: 179-186.

OPALINSKI P. \& HARLAND T.L. 1981. The Middle Ordovician of the Oslo Region, Norway, 29. Stratigraphy of the Mjøsa Limestone in the Toten and Nes-Hamar areas. Nor. geol. Tidsskr, 61: 59-78.

PARCHA S.K. \& PANDEY S. 2011a. Trace fossil and their significance in the Cambrian successions of the Parahio Valley in the Spiti Basin, Tethys Himalaya, India. J. Asian Earth Sci., 42: 1097-1116.

PARCHA S.K. \& PANDEY S. 2011b. Devonian Ichnofossils from the Farakah Muth Section of the Pin Valley, Spiti Himalaya. J. Geol. Soc. India, 78: 263-270.

PASCHER A. 1931. Systematische übersicht über die mit Flagellaten in Zusammenhang stehenden Algenreihen und Versuch einer Einreihung dieser Algan stämme in die Stämme des Panzenreiches. Beih. Bot. Zentralbl., 48: 317-332.

PAYRI C.E. 1988. Halimeda contribution to organic and inorganic production in a Tahitian reef system: Coral Reefs, 6: 251-262.

PIA J. 1920. Die Siphoneae verticillatae vom Karbon bis zur Kreide. Abh. Zool.-Bot. Ges. Wien, 11(2): $1-263$.

PIA J. 1927. Die Erhaltung der fossilen Pflanzen. Part 1, Thallophyta. In: Hirmer M. (ed.), Handbuch der Palaobotanik: Berlin and München, 1: 1-136.

RANGA RAO., DHAR,C.L., RAO S.V. \& SHAH S.K. 1982. Contribution to the stratigraphy of Spiti. Himalayan Geol., 12: 98-113.

REED F.R.C. 1912. Ordovician and Silurian fossils from the cantral Himalaya. Pal. Indica, Series 15, 7/2: 1-168 Calcutta.

RIDING R. \& FAN J. 2001. Ordovician calcified algae and cyanobacteria, northern Tarim basin subsurface, China. Palaeontology, 44(4): 783-810. 
ROUX A. 1991. Ordovician to Devonian marine calcareous algae: 349-369. In: Riding R. (ed.) Calcareous algae and stromatolites. Spinger-Verlag, Berlin Heidelberg.

TAPPAN H. 1980. The paleobiology of plant protists. Freeman, San Francisco, USA, 1028 p.

SINHA H.N. \& TRAMPISCH C. 2013. Calcareous Algal Association from the Lower Paleozoic Tethyan Sedimentary Sequence of the Shiala Formation, Indian Gondwana. J. Geol. Soc. India, 82: 339-350.

SMITH A.G. 2001. Paleonagnetically and tectonically based global maps for Vendian to mid-Ordovician time: 11-46. In: Zhuravlev A.YU. \& Riding R., (eds), The ecology of Cambrian radiation. Columbia University Press, New York..

SRIKANTIA S.V. 1981. The lithostratigraphy, sedimentation and structure of the Proterozoic-Phanerozoic formations of Spiti basin in the Higher Himalayas of Himachal Pradesh India: 31-38. In: Sinha A.K. (ed.), Contemporary Geoscientific Research in Himalaya. 1. Bishen Singh Mahendra Pal Publisher, Dehradun, India.
SRIKANTIA S.V. \& BHARGAVA O.N. 1998. Geology of Himachal Pradesh. Geological Society of India.

STOLLEY E. 1893. Ueber silurische Siphoneen. Neues Jahrb. Mineral., Geol. Palaéontol., 2: 135-146.

STOLICZKAI F. 1865. Geological sections across the Himalayan Mountains, from Wangtu bridge on the river Satluj to Sumdo on the Indus: with an account of formations of Spiti, accompanied by a revision of all known fossils from the district. Memoir Geol. Surv. India, 5(1): 1-173.

SUTTNER T. \& ERNST A. 2007. Upper Ordovician Bryozoan of the Pin Formation (Spiti Valley, Northern India). Palaeontology, 50(6): 1485-1518.

TALENT J.A., GOEL R.K., JAIN A.K. \& PICKETT J.W. 1988. Silurian and Devonian of India, Nepal and Bhutan. Biostratigraphic and Palaeobiogeographic Anomalies. Cour. Forsch-Inst. Senckenberg, 106: 1-57.

WEBBY B.D. 2002. Patterns of Ordovician reef development: 129-179. In: Kiessling W., Flügel E., Golonka J. (eds) Phanerozoic reef patterns, Spec Publ 72. SEPM (Society for Sedimentary Geology), Tulsa. 